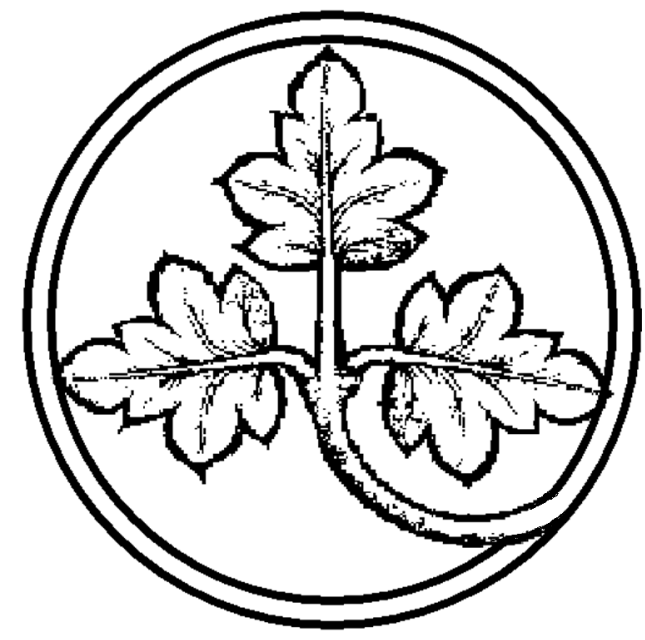

Gemeinschaftsgüter: Recht, Politik und Ökonomie

\author{
Preprints \\ aus der Max-Planck-Projektgruppe \\ Recht der Gemeinschaftsgüter \\ Bonn \\ $2001 / 4$
}

A Constitutional Framework for Private Governance

Von

Christoph Engel 


\title{
A Constitutional Framework for Private Governance
}

\author{
Christoph Engel
}

March 2001

Max-Planck-Projektgruppe Recht der Gemeinschaftsgüter, Poppelsdorfer Alle 45, 53115 Bonn www.mpp-rdg.mpg.de 


\section{A Constitutional Framework for Private Governance}

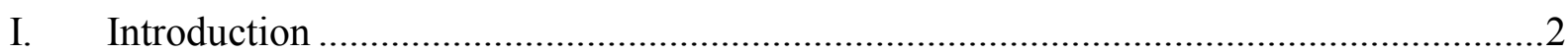

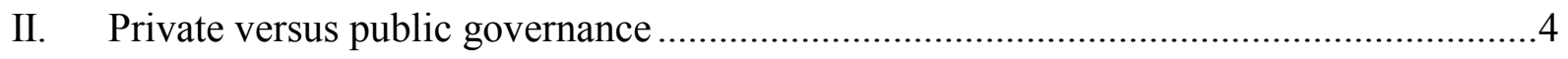

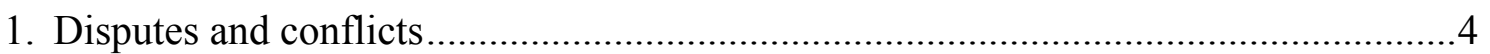

2. Constitutional protection from governmental interference into private regulation in

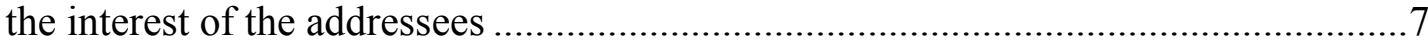

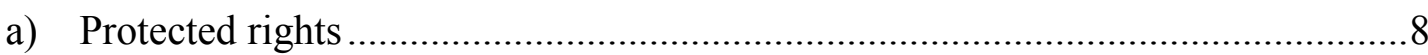

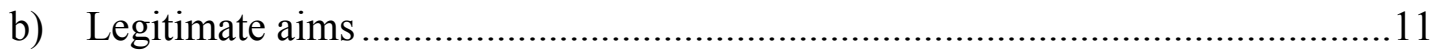

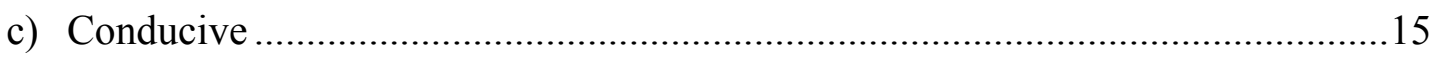

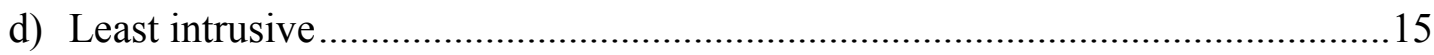

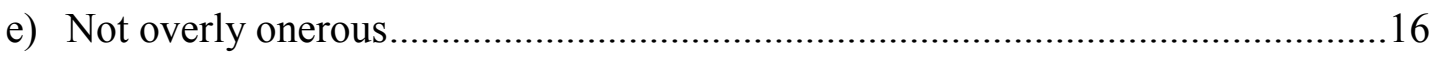

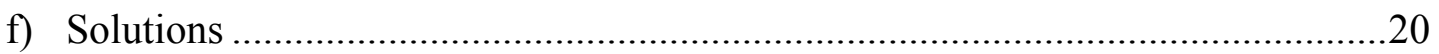

3. Other disputes between private regulators and government...................................21

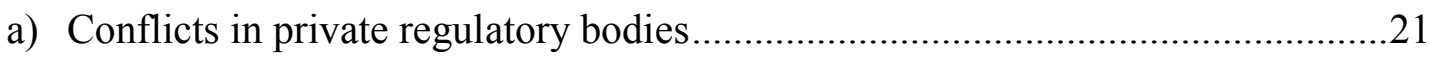

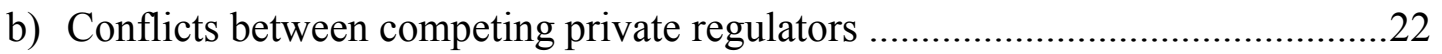

c) Competition between private and public regulation .........................................24

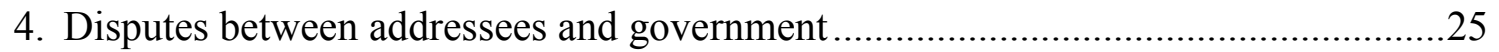

a) Protection from public intervention into private regulation ...............................25

b) Call for protection against private regulation .................................................26

5. Disputes between protectees and government..................................................29

a) Protection from public intervention into private regulation ...............................29

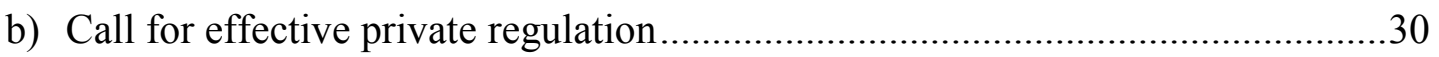

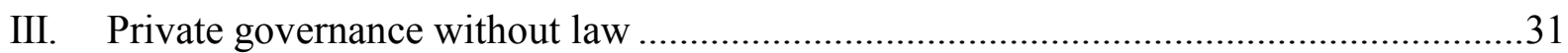

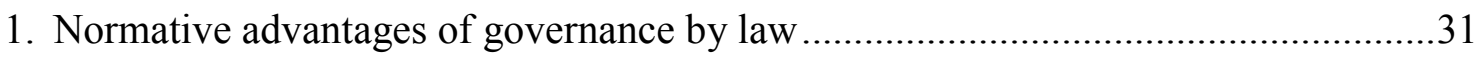

2. Constitutional status of governance by law .............................................................. 33

IV. Conclusion: From pure private to hybrid regulation .....................................................34

* I am indebted to Adrienne Héritier, Florian Becker and Tanja Börzel for helpful comments, and to Darrell Arnold for the linguistic trimming of the paper. 


\section{Introduction}

Lawyers are the engineers of the social sciences, and their doctors. Neither is good for a reputation in interdisciplinary exchange. Social scientists often show contempt for a discipline that seems too close to reality to meet hard methodological standards and too much concerned by pathologies that are beyond the reach of its methodological tools. As with many prejudices, there is a grain of truth in this one. But not all law is about making decisions and judgements in the face of a reality that is at best partly understood. The legal discipline has its own methodological standards. For the sake of internal clarity, it aims at parsimony. But modelling is not the legal path to methodological rigor. The legal equivalent boils down to one simple question: who asks whom for what? The law splits abstract problems into a series of cases. It reaches parsimony via the selection and sequence of cases. These hypothetical cases are like histological cuts through the social tissue. The legal discipline starts cutting at cases for which existing legal tools seem particularly well-suited. If these cases are understood, the legal discipline then starts again with the more demanding ones. It is hoped that the sequence of cases leads to an understanding of situations that seemed inaccessible at the outset.

The following article tries to apply this method to hybrid forms of governance in a multilevel setting. This concept puts an end to the idea that government has a monopoly on governance. In the vertical dimension it adds the existence of international, regional and local regulators. In the horizontal dimension it adds both regulatory competition in governance and the possibility of a private element in governance. Such forms of composite governance are frequent in practice, and many of them perform well. But they are too complex for the dogmatic tools available for addressing them in legal terms. This is why this article deliberately ignores the practical prominence of the composite forms. It rigorously simplifies the case it starts with and adds complexity step by step, or case by case. The initial case is not exactly counterfactual. But it is not clear where such a case would ever come before a court; neither is it the case most prominent for legal practice, nor the one ranking highest in social scientific interest.

For lawyers, governance is a constitutional issue. One can legitimately ask whether the European Union possesses the functional equivalent of a constitution ${ }^{1}$. One can even go 
beyond that and ask whether the United Nations Charter or the World Trade Organisation Treaty are elements of an incumbent world constitution ${ }^{2}$. But at present constitutional law still is basically national law. And the following investigation is confined to the constitution I know best, the German constitution.

The first simplification concerns the type of deviation from the traditional state monopoly of governance. The first part of this article looks at what is rather rare in practice: pure private governance (II). It is only in the conclusion of the article that I will look at more complex forms of the governance (IV). The second simplification concerns the governance tool employed. I start with the case of (pure private) governance by law. Such judicial pure private governance is even less frequent in practice. Most private governance is not legal in nature. Rather, it uses social norms or a technical code. Later in the paper I will try to face the intellectual challenge connected with this (III). The third simplification concerns the parties of the hypothetical case. It assumes a case in which the government takes legal action against the private governance body in the interest of its addressees. The opposite scenario, however, is much more probable. In this scenario, an addressee claims that government protect it against private regulatory power. This latter case is dogmatically much more demanding. I will take it up only after I have offered a solution to the easier case ${ }^{3}$.

Since these simplifications are on purpose artificial, it would not be advisable to illustrate what is to follow by a case taken from governance practice. Any such case would perforce add context, and the context would divert the attention from the topic of the analysis. But even a case made up cannot eschew a further dimension of complexity. If government itself governs, a constitutional lawyer can take its power to impact on society for granted. It derives from its sovereign powers, i.e. from the constitution itself. This is not true for private governance. The private regulator must subdue addressees to its governance activities. This doubles the constitutional issues. The constitution potentially has a say on both the submission of the addressee under private governance, and on the exercise of these powers. By a fourth simplification, in what follows this distinction is assumed away. Dogmatically, this is feasible in two forms. In the first scenario, the constitutional review concentrates on the act of submission. It assumes that the constitutional lawyer can predict how the private

Verfassungsrecht; Gertrude Lübbe-Wolff: Europäisches und nationales Verfassungsrecht, in: Veröffentlichungen der Vereinigung der Deutschen Staatsrechtslehrer 60 (Forthcoming). Gesellschaft für Völkerrecht 39 (2000) 427-448. 
governance body, once established, will exercise its regulatory powers. In the second scenario, constitutional control of single governance acts actually has two combined issues: the act itself, and the act of submission to private governance power.

Along these lines, the artificial example from which the following analysis starts is this: an industry offers a credence good. Information economics distinguishes credence from inspection and experience goods. The ordinary buyer of an inspection good can himself and on the spot find out whether the good has the promised quality. Experience goods have hidden properties that can only be uncovered over time. For credence goods, even individual experience does not suffice. The buyer must believe the seller's statements. Rational buyers are reluctant to do so, for fear of cheating ${ }^{4}$. A classic example are the professions, like doctors. Assume thus a doctors' association. Doctors have freely become members of the association. The association has power to define good medical practice in a code of private law, and to enforce the code on its members by private law sanctions ${ }^{5}$.

A last simplification concerns the scope of the argument. The analysis presupposes a national case. Extending constitutional protection to cross-national private or hybrid governance would make for another article.

\section{Private versus public governance}

\section{Disputes and conflicts}

Before I can set out to explore my initial case, I have to describe in somewhat greater detail the landscape of which this case is an element. Governance is characterised by one actor influencing a second in the interest of a third. Since formal government does not disappear, private governance is thus characterised by four classes of primary actors: government, private regulators, addressees and protectees of regulation. In our illustrative case, these would be government, the doctors' association, its members, and their patients. Any member

The standard text is George A. Akerlof: The Market for 'Lemons'. Quality Uncertainty and the Market Mechanism, in: Quarterly Journal of Economics 84 (1970) 488-500.

5 Reality in Germany is different. Public law makes the admission of doctors to practice conditional upon membership in the competent doctors' chamber. Moreover, the chamber acts under public, not under private law, when it defines good medical practice and sanctions the standards. 
of one of these classes can come into conflict with any member of any other class. Let us briefly sketch out the possible conflicts.

Private regulators might perceive public action as unfair regulatory competition ${ }^{6}$. Addressees might consider private regulation less onerous than public regulation ${ }^{7}$. Protectees might feel that private regulation offers better protection than public intervention ${ }^{8}$. All these conflicts lead into straightforward constitutional litigation. The private party attacks the respective statutory provision by way of constitutional complaint. It grounds its complaint on the view that the government is interfering with one of its fundamental freedoms. The dogmatic investigation starts in its simplest form, the case looking like a classic bipolar statecitizen conflict. The multipolar character of the conflict only becomes visible when the Constitutional Court checks for justifications.

But there are more conflicts out there. A first set of conflicts opposes the private regulator to the remaining two classes of actors: an addressee dislikes the ensuing limitation on his freedom ${ }^{9}$, or a protectee claims a right to better protection ${ }^{10}$. Finally, a protectee and an addressee can be directly in dispute over the appropriate degree or form of protection ${ }^{11}$. Of course, any of these conflicts can lead to litigation in the civil courts. But in these courts the conflict is, at best, indirectly discussed as a constitutional issue. This is possible since the civil courts are empowered to construe statutory provisions in light of the constitution. But it is not possible for them to invalidate or disregard a statutory provision. If they are convinced that a case violates constitutional standards, they must ask the Constitutional Court for a preliminary ruling (Art. 100 par. 1, Basic Law). These procedural features of the German legal order explain why constitutional law has developed its own solutions to conflicts between private parties. One solution is straightforward. Government takes the issue up and legislates on behalf of one of the conflicting parties. The conflict becomes a constitutional case if one of the addressees of these statutory provisions attacks it in court. This is the scenario from which our analysis will start. Government intervenes into private regulation in the interests of its addressees $^{12}$, i.e. it intervenes into the regulatory activities of the association on behalf of the doctors. In this scenario, all actors swap roles. The private regulator becomes the addressee of

\footnotetext{
See below $3 \mathrm{c}$.

See below 4 a.

See below 5 a.

See below 2 and $4 \mathrm{~b}$.

See below 5 b.

See below 5 b.
} 
public intervention. And the addressee of private regulation becomes the protectee of public intervention. Finding a dogmatic way for bringing the protectee of private regulation back into the constitutional picture is the most demanding challenge of this scenario.

But the German constitution does not stop here. Fundamental freedoms do not only protect individuals and groups from government interference. In principle, they work the other way around, too. Government can thus be constitutionally obliged to protect one group of private actors from other private actors' intrusions on their freedom ${ }^{13}$. If a private party relies on this duty to protect, the rules in constitutional litigation are turned upside down. It is now the addressee, or a doctor, who sues the government for not having intervened into private regulation on his behalf ${ }^{14}$. And the protectee, or a patient, comes back to the fore, suing the government for not having forced private regulators to be more effective on his behalf ${ }^{15}$.

As complex as this already is, it is not yet the full constitutional picture; for the black box of private regulators is still to be opened. In practice, private regulation is primarily "selfregulation". The classic case is an industry, which agrees on a quality standard and imposes it on all its members. In practical terms this presupposes well-organised industrial associations. In such a scenario, the true conflict is between the management of the association and some of its members. Government can intervene in the interest of protecting the members against the management ${ }^{16}$. Members can claim that the government has a duty to protect them from the powerful management ${ }^{17}$. This clarification forces us to soften one of the original simplifications in the illustrative case. The doctors' association actually falls into this second category, if it acts vis-à-vis its members. It falls into the previous category, if it tries to force outside doctors to become a member, or to abide by its standards although they are not formally a member.

Another line of conflict opposes competing private regulators, like several doctors' associations, offering different standards of good medical practice. One of them can feel that the other engages in unfair regulatory competition. If they sell regulation, there is also a

See below 2.

Comprehensivly Johannes Dietlein: Die Lehre von den grundrechtlichen Schutzpflichten, Berlin 1992.

See below $4 \mathrm{~b}$.

See below $5 \mathrm{~b}$.

See below 3 a.

Dogmatically, this case does not pose new questions. It is therefore not explicitly dealt with here. 
danger of unfair economic competition. Again, government can intervene on behalf of the weaker regulator $^{18}$. Or a regulator can invoke a constitutional duty for protection ${ }^{19}$.

From this follows the structure of the section. It is organised according to the types of disputes. Private regulators (2-3), addressees (4) and protectees of private regulation can sue government (5). But we know already that these disputes regularly hide conflicts between different persons. Government intervenes into the action of private regulators to protect addressees against regulators (2), to solve conflicts at the interior of private regulatory bodies, between competing private regulators or between private and public regulation (3). The same holds true, mutatis mutandis, for the disputes between addressees or protectees of private regulation and government.

\section{Constitutional protection from governmental interference into private regulation in the interest of the addressees}

Our first case addresses the basic constitutional issues inherent in private regulation, but it does so from an angle that simplifies the discussion. It assumes that government has legislated in favour of the addressees of private regulation. Such legislation can then be attacked by the affected private regulators. In our illustrative case, government is sued by the association for having intervened, in the interest of individual doctors, into the formulation of standards for good medical practice. The Constitutional Court will address the following dogmatic questions: Does this statute interfere with a private regulator's constitutionally protected rights (a)? Can government show that the intervention is constitutionally legitimate (b)? Is the statute conducive to this $\mathrm{end}^{20}$ ? Is it the least intrusive measure that would be equally effective $^{21}$ ? Is it not overly onerous, given the constitutional status of both the protected right and the legitimate $\operatorname{aim}^{22}$ ? The first test, and partly also the third one, do look at the conflict between government and private regulators in isolation (c). The second and third tests call for a comparison between the actual intervention and alternative means for reaching the same end. This makes it possible to bring the interests of addressees into play (d). But as we already

\footnotetext{
See below $3 \mathrm{~b}$.

Again, this duty to protect is not investigated, since it poses no new dogmatic questions.

"geeignet".

"erforderlich".

"angemessen"; for a comprehensive overview of the dogmatics of fundamental freedoms as developed by the German Constitutional Court, see Jörn Ipsen, Staatsrecht II Grundrechte (Juristische Lernbücher 36) Neuwied $^{3} 2000 \S 3$.
} 
know, our conflict is one between four parties. How can the fourth party, the protectees of private regulation, dogmatically be inserted into the picture (e)? This section ends with a sketch of possible compromises (f).

Visually, the case under review here can be characterised as follows:

\begin{tabular}{|c|c|c|c|c|}
\hline & protectee & addressee & private regulator & government \\
\hline dispute & & & & $\rightarrow$ \\
\hline conflicts & & & & \\
\hline
\end{tabular}

\section{a) Protected rights}

A German constitutional lawyer is taught that any governmental interference into freedom is a constitutional issue. The catalogue of specific fundamental freedoms is so rich that it is normally not difficult to show the case to be within the purview of at least one of these freedoms ${ }^{23}$. Should this attempt fail dismally, there is always Article 2, par. 1, Basic Law. The Constitutional Court interprets this provision as a subsidiary general freedom ${ }^{24}$. At first sight, government intervention into private regulation does not look like an exception to this rule. If the private body sells its regulatory activities for a profit, it can invoke its economic freedom as protected by article 12, Basic Law ${ }^{25}$. If the regulatory output can be stored, like a book of rules, the regulator can claim this to be his constitutionally protected property under Article 14, Basic $\mathrm{Law}^{26}$. If the regulator uses a contract to exercise regulatory influence on addressees, it can invoke freedom of contract as protected by Article 2, par. 1, Basic Law ${ }^{27}$.

For a comprehensive overview see Ipsen (note 22) § 4-17.

Leading cases BVerfGE 6, 32 - Elfes; BVerfGE 80, 137 - Reiten im Walde.

For the details see Ipsen (note 22 ) $§ 15$.

For the details see Ipsen (note 22) $\S 17$; intellectual property will usually be more important than physical, but it also falls under article 14, BVerfGE 49, 382.

27 See in detail Wolfram Höfling: Vertragsfreiheit. Eine grundrechtsdogmatische Studie (Schriften zum Wirtschaftsverfassungs- und Wirtschaftsverwaltungsrecht 26) Heidelberg 1991. 
Many private regulatory activities are linked to specific fundamental freedoms, like freedom of expression (article 5, Basic Law ${ }^{28}$ ) or freedom of religion (article 4, par. 1, Basic Law) ${ }^{29}$.

But in our case, a lawyer might wrongly feel assured. For government interferes into private regulation. Private regulation is the functional equivalent to public regulation. Does the constitution indeed regard an activity that mimics government to be protected by fundamental freedoms? To be sure, the protection by fundamental freedoms does not end where one person impinges upon the activity of another who is equally protected by fundamental freedoms. It is the task of government to find solutions to such conflicts. And in doing so it has to pay due regard to the fundamental freedoms of both parties ${ }^{30}$. The fundamental freedoms do not even end when a person deliberately exercises power over another ${ }^{31}$. But private regulation is different. The private body purports to replace government or at least to engage in competition with public regulation ${ }^{32}$.

There are two conceptual possibilities to explain the difference, one rather critical, the other more benign. The critical concept dates as far back as 1762. In that year Jean Jacques Rousseau published his "Contrat social". In that book he distinguishes healthy volonté génerale from dangerous volonté de tous. By the latter term he means governance by and in the interests of groups ${ }^{33}$.

The more benign concept is to be found in cultural theory. This theory offers an analytic framework for theoretically incompatible normative starting points. It classifies them into four basic classes: the hierarchical, the individualistic, the egalitarian and the fatalistic ${ }^{34}$. Fatalists believe that the government's efforts just make no difference. Each of the other three ways of life has its predilection for one institutional arrangement: Hierarchists believe in central government, individualists in the market, egalitarians in self-regulation ${ }^{35}$.

For the details see Ipsen (note 22) $§ 10$.

29 For the details see Ipsen (note 22) § 9 - I deliberately do not mentioned article 9, Basic Law, at this point, see further below in this section. comprehensive Konrad Hesse: Grundzüge des Verfassungsrechts der Bundesrepublik Deutschland, Heidelberg $^{20} 1995$, R $317-320$.

$31 \quad$ Leading case BVerfGE 50290 - Mitbestimmung.

32 For the competitive aspect see below $3 \mathrm{c}$.

33 Jean Jacques Rousseau: Contrat Social, Paris 1762, Book II Chapter III.

34 Basic Michael Thompson/Richard Ellis/Aaron Wildavsky: Cultural Theory, Boulder 1990.

35 Stimulating on both the performance and the possibility conditions Elinor Ostrom: Governing the Commons. The Evaluation of Institutions for Collective Actions, Cambridge 1990.
} 
The German constitution has a balanced view. Unlike the French constitution ${ }^{36}$, it does not ban egalitarian approaches. But my claim is that it dogmatically distinguishes the protection of egalitarian autonomy from the protection of individualistic freedom ${ }^{37}$. This is obvious in Article 28, par.2, Basic Law. This article protects the autonomy of municipalities. The Constitutional Court has put it beyond doubt that the provision is limitational. Municipalities are entitled to participate in private law exchange. But if government interferes in such exchanges, the municipalities cannot defend themselves by means of fundamental freedoms like the freedom of property. They are not holders of these freedoms ${ }^{38}$.

For other cases of self-regulation, constitutional jurisprudence is less clear. Article 9, par.3, Basic Law, protects unions, employers' associations and their collective agreements. The Constitutional Court has interpreted this activity as a "public task" 39 . But it is only in the jurisprudence of the Federal Court for Labour Law that collective arrangements are directly tested against the standards of fundamental freedoms ${ }^{40}$. Another line of constitutional jurisprudence is even less satisfactory. Article 19, par.3, Basic Law, makes it clear that, in principle, legal persons of public law are not protected by fundamental freedoms. The Constitutional Court makes an exception for universities ${ }^{41}$, public broadcasters ${ }^{42}$ and for publicly organised churches ${ }^{43}$. According to the court, all of these public entities deserve protection due to "the character of their activities which is similar to the use of fundamental freedoms". All dogmatic clumsiness disappears if one acknowledges the difference between freedom and autonomy. The listed entities or activities do indeed deserve protection from hierarchical intervention. But the reason for this is not their individualistic, but their egalitarian character. This character is what counts constitutionally, not the public or private organization or the public or private form of action ${ }^{44}$.

I owe this stimulating comparison to Fritz Scharpf.

To the extent that the question has been asked by constitutional lawyers, they seem to be rather sceptical, see in particular Reinhard Hendler: Selbstverwaltung als Ordungsprinzip. Zur politischen Willensbildung und Entscheidung im demokratischen Verfassungsstaat der Industriegesellschaft, Cologne 1984; Winfried Kluth: Funktionale Selbstverwaltung. Verfassungsrechtlicher Status - Verfassungsrechtlicher Schutz (Jus Publicum 26) Tübingen 1997.

Leading case BVerfGE 61, 82, 105 - Sasbach.

BVerfGE 28, 295, 304.

BAGE 1, 185, 193; even this court now makes a difference, BAGE 52, 88, $97 \mathrm{~s}$.

BVerfGE 15, 256, 262.

BVerfGE 31, 314, $321 \mathrm{~s}$.

BVerfGE 19, 1, 5.

Constitutional lawyers sometimes posit the opposite, see e.g. Kluth (note 37) 28.
} 
If one accepts this view, it finally casts new and elucidating light on Article 9, par. 1, Basic Law. This provision protects the freedom to form associations and corporations. The Constitutional Court extended the protection to the activities of these entities once there are founded. And it holds that not only the founders, but also the entity itself is protected, irrespective of whether the entity has legal personality or not ${ }^{45}$. One has an individualistic freedom to form business corporations. If such corporations exert power on the market, a conflict among individuals originates. The formation of an association is different, however. In light of the forgoing, this provision ought to be interpreted as the general clause for the protection of egalitarian rule. Article 9, par.1, Basic Law, turns out to be the general clause for the protection of autonomy, not freedom. The rest of this article will concentrate on this provision.

\section{b) Legitimate aims}

The Constitutional Court has given fundamental freedoms the following dogmatic structure: It starts from the governmental act against which the constitutional claim is directed. The court first asks whether this act interferes with the subject matter of a fundamental freedom. If it does, it has to meet formal and substantive limitations. The substantive limitations consist of the four tests already mentioned: the act has to serve a legitimate aim, it must be conducive to this end, it must be the least intrusive act of intervention that is equally conducive, and it may not be overly onerous ${ }^{46}$.

If one follows those who classify Article 9, par.1, Basic Law, in its entirety as a fundamental freedom, one can simply apply these tests ${ }^{47}$. If one interprets Article 9, par. 1, Basic Law, as the general clause for the protection of autonomy, an additional dogmatic question comes to the fore: Do constitutional norms for the protection of autonomy have the same dogmatic structure? The Constitutional Court has addressed the question with respect to the autonomy of municipalities. Although the wording is different, it has basically transposed

$45 \quad$ BVerfGE 13, 174, 175.

46 In German, the four tests are usually called: "Legitimer Zweck, Geeignetheit, Erforderlichkeit, Angemessenheit", see only BVerfGE 67, 157, 173 and basic Peter Lerche: Übermass und Verfassungsrecht. Zur Bindung des Gesetzgebers an die Grundsätze der Verhältnismässigkeit und der Erforderlichkeit (Bibliothek des Öffentlichen Rechts 10) Goldbach ${ }^{2} 1999$.

47 The only question may be whether any legitimate aim is sufficient (BVerfGE 30, 227, 243) or whether Article 9, par. 2, Basic Law is limitational, too (von Mangoldt/Klein/Starck-Kempen) ${ }^{4}$ article 9 GG, R $163 \mathrm{~s}$. 
the dogmatics of the fundamental freedoms ${ }^{48}$. This makes sense. Individualistic freedom and egalitarian autonomy are different. But if hierarchical government intervenes into one of them, it must show that it does so for good reason, and that the intervention is not disproportionate.

In the hypothetical case under review here, government does not intervene for its own sake. It purports to protect the addressees of private regulation. The material conflict is thus not one between hierarchy and autonomy, but between autonomy and liberty. Constitutional jurisprudence allows the government to intervene into the freedom (or autonomy) of one group in the interest of the constitutionally protected freedom of another group ${ }^{49}$. According to this perspective, private regulation boils down to an instance of private power. The argument has two facets. The first is straightforward. In order to reach its regulatory end, private regulation has to exercise power over addressees who are unwilling to play by these rules. Private regulators are often quite ingenious at hiding this effect. The most prominent case is regulation by technical code. The solution is literally hard-wired ${ }^{50}$.

The second facet of the argument is more elaborate. It relies on the insight that most regulatory tools have a distribution effect. They do effectively address some social problem. But there could be other solutions with a different distributional balance sheet ${ }^{51}$. This is already a plausible explanation for what economists have called "the market for regulation" ${ }^{52}$. Such private-interest regulation becomes even more attractive if the interested group can take regulation into its own hands ${ }^{53}$.

BVerfGE 79, 127, 146 ss. and in particular 152 ss. - Rastede; for the (small) differences see e.g. Friedrich Schoch: Zur Situation der kommunalen Selbstverwaltung nach der Rastede-Entscheidung des Bundesverfassungsgerichts, in: Verwaltungsarchiv 81 (1990) 18-54 (26 ss.).

According to established jurisprudence, this power is not limited to fundamental freedoms that give it explicitly to government. Any fundamental freedom is, in other words, an implicit limitation to any other, BVerfGE 39, I 43. This is the dogmatic effect of the already-mentioned principle of practical concordance, see above at note 30 . As long as the contents of private regulation remains unspecified, one cannot determine which freedoms of addressees the government could rely on.

This is the main point of Lawrence Lessig: Code and Other Laws of Cyberspace, New York 1999, 6, 13 and passim; James Boyle: Foucault in Cyberspace. Surveillance, Sovereignty and Hard-Wired Censors, in: University of Cincinnati Law Review 66 (1997) 177 - 205 (177 and passim).

Basic George J. Stigler: Theory of Economic Regulation, in: Bell Journal of Economics 2 (1971) 3 - 21.

Characteristic A. Michael Froomkin: Of Government and Governance, in: Berkeley High Technology Law Journal: "it is another thing to tolerate private sector leadership when it clothes itself in the guise of 'bottom-up rulemaking' but actually seeks to use government or government-like power to lock in advantages enjoyed by established firms, often at the expense of consumers or new competitors". 
At this point we are not interested in the principal-agent problem between the management of an association and its members ${ }^{54}$. However, this does not mean that only the constitutionally protected freedom of outsiders could be used by government as a defence for the intervention into private regulation. Actually, private regulatory power over outsiders is relatively infrequent in practice. The already-mentioned governance by technical code is a case in point. Another is the filtering of Internet content by Internet service providers like America Online. By denying their customers access to parts of the internet, AOL exerts power over the persons responsible for these contents ${ }^{55}$. But inside the regulatory association, regulation is much easier. It can rely on the management powers laid down in the charter of the association.

This very fact often makes government protection constitutionally more demanding. If their membership is not voluntary, insiders are constitutionally no different from outsiders. Sometimes the law obliges persons to become members of an association ${ }^{56}$. In other instances, the demand side of a market makes it paramount for a firm to be a member of a business association ${ }^{57}$. If none of these qualifications applies, the constitution must weigh the importance of consent. In the relationship between government and citizens, consent does not make constitutional protection disappear. Fundamental freedoms are thought to be nonderogable $^{58}$. If government relies on the fundamental freedoms of one group in order to intervene into the freedom or autonomy of another, the situation is even clearer. If the members of the association have waived a right at all, then they have done so vis-à-vis the association, not vis-à-vis government. But the fact that they have freely decided to become a member of the association has to be taken into account when assessing whether government interference into private regulation is disproportionate ${ }^{59}$.

From this vantage point, the dogmatic solution to a related problem becomes visible. There is a second difference between insiders and outsiders. Insiders typically have legally framed

See below 3 a.

Critical for that reason David G. Post: Governing Cyberspace, in: Wayne Law Review 43 (1996) 154 171 (at footnote 30 ).

This holds true for many German businesses, which are legally obliged to be a member of the respective business chamber. These chambers usually have some regulatory authority. For an overview of the complicated practice see Rainer Pitschas: Recht der Freien Berufe, in: Reiner Schmidt (ed.), Öffentliches Wirtschaftsrecht Besonderer Teil A 2, Berlin 1996, 1- 126.

$57 \quad$ See again Akerlof Quarterly Journal of Economics 1997 (note 4).

58 This position is not unquestioned, and the constitutional jurisprudence is not fully clear. For the details see Klaus Stern: Das Staatsrecht der Bundesrepublik Deutschland III Allgemeine Lehren der Grundrechte $\S 86(897-899)$ on constitutional jurisprudence.

See below e. 
ways to influence the management of associations. Albert O. Hirschman has coined the terms "voice" and "exit" for the two basic mechanisms ${ }^{60}$. Members have rights to control and influence management decisions. And they can leave the association if they dislike its behaviour. The stronger the options for voice and exit, the more difficult it is to justify government intervention.

Practical concordance is not limited to conflicting fundamental freedoms. The constitution has to be interpreted as a unit. Government may therefore also intervene in the interest of protecting objective constitutional law $^{61}$. The prime concerns stem from the principle of democracy, guaranteed by article 20, par.1, Basic Law ${ }^{62}$. There is a danger of this state being decomposed into a bunch of uncoordinated single-issue constituencies ${ }^{63}$. Private regulatory bodies usually lack checks and balances ${ }^{64}$. Since we have at this point narrowed our perspective to private governance by law, the related concern with the rule of law is weakened. It is confined to the difference between public and private law. The organisation and procedure of civil-law courts is adapted to solve conflicts between private parties, not to judicially test regulation.

The remaining two concerns are not easy to locate in German constitutional law. To the extent that private ordering is private-interest regulation, it has a distributional effect ${ }^{65}$. The German constitution is not silent on distribution. According to Article 20, par.1, Basic Law, the Federal Republic is a "social" state. But does the provision encompass the constitutional disapproval of distributionally biased regulatory institutions? The dogmatic uncertainty is even greater with respect to distortions in market exchange. Not so rarely, private regulation does indeed have this effect. This is obvious if the regulating association assembles all the members of an industry. At the very least, this association brings about a standardisation of

Albert O. Hirschman: Exit, Voice and Loyalty, Cambridge 1970.

61 Hesse (note 30) R 317 - 319. Those with a less liberal attitude towards practical concordance (for an overview see Stern [note 58] § 81 IV) do not reach a different result, but they have to use a different dogmatic technique. They have to interpret the conflicting fundamental freedoms in light of corroborating objective constitutional law.

From the many doctrinal voices see only the following three: Udo Di Fabio: Verwaltung und Verwaltungsrecht zwischen gesellschaftlicher Selbstregulierung und staatlicher Steuerung: Veröffentlichungen der Vereinigung der Deutschen Staatsrechtslehrer 56 (1997) 235 - 282 (263 - 268); Neil W. Netanel: Cyberspace Self-Governance. A Sceptical View from Democratic Theory, in: California Law Review 88 (2000) 395-498; Walter Leisner: Verfassungsgrenzen privater Selbstregulierung, in: Michael Kloepfer (ed.): Selbst-Beherrschung im technischen und ökologischen Bereich. Selbststeuerung und Selbstregulierung in der Technik-Entwicklung und im Umweltschutz (Schriften zum Umweltrecht 85) Berlin 1998, 151 - 162 (151): there is a "danger that all anti-power mechanisms of public law fail". I owe this thought to Kenneth H. Keller.

64 On the danger of excessive efficacy see below III 1. 
product quality. And there is always the temptation to go further. But it is now settled jurisprudence that the German constitution has not explicitly opted for a market economy ${ }^{66}$. There are at best indirect ways to reach this dogmatic outcome, for instance, by interpreting the Basic Law in light of pertinent provisions in the Treaty of the European Community ${ }^{67}$.

\section{c) Conducive}

Under the principle of proportionality, interference with a fundamental freedom or with constitutionally protected autonomy must first be conducive to the governmental aim. In our case, the government intervenes in order to protect those addressed by private regulation. Of course, whether the test is met depends of the nature of the concrete act of intervention. But this will normally not pose a problem.

\section{d) Least intrusive}

Normally the second constitutional test will not be more difficult for government to meet. It obliges the government to use the least intrusive measure, given the legitimate aim. This test calls for a comparison between the measure actually chosen and hypothetical alternative measures. The test takes the legitimate aim for granted. It directs the Constitutional Court to answer two questions: Are there other measures that would be equally likely to further the legitimate aim? If so, are any of these measures less onerous for the constitutional claimant? The answer to the first question crucially depends on the nature of the legitimate aim. In our case, this means: Would any other governmental intervention give the addressees of private regulation equal or even better protection?

Critical for our topic is the second question. At face value, it seems to look exclusively at the interests of private regulators. Yet, if that were true, the constitution would not be able to look at the quadrangle of interests. It would artificially narrow it down to a triangle, ignoring the interests of protectees. A close look reveals that this impression is false. It is precisely at

See above at note 51 .

BVerfGE 4, 7, 17 s. ; 50, 190, 337; from the abundant literature see only Christian Koenig: Die öffentlich-rechtliche Verteilungslenkung. Grund und Grenzen einer Deregulierung am Beispiel der Vergabe von Konzessionen, Kontingenten und Genehmigungen zur unternehmerischen Nutzung öffentlich verwalteter Güter (Schriften zum öffentlichen Recht 655) Berlin 1994, 51 - 71.

See only art. 4 par.1 EC Treaty, more from Christoph Engel: Europarechtliche Grenzen für die Industriepolitik, in: Hans-Werner-Rengeling (ed.): Europäisierung des Rechts (Osnabrücker Rechtswissenschaftliche Abhandlungen 50) Cologne 1996, 35 - 67 (46 - 52). 
this point that the difference between the constitutional protection of freedom and of autonomy matters most. Were private regulation only indirectly protected, as an exercise of individual freedom, it would indeed be difficult to bring the interests of protectees into play. That could best be done where the interests of private regulators and protectees fully coincided. However, if the constitution protects private regulatory autonomy, the problem disappears. According to this perspective, private regulatory activities are not protected as a means for making money or for doing something rewarding. It is the regulatory quality that counts. Accordingly, governmental intervention into private regulation is "less onerous", if it impedes less on the quality of the private regulation.

\section{e) Not overly onerous}

Understanding the difference between freedom and autonomy becomes even more important for defining the right standard under the last test. It is not private regulators' freedom that has to be balanced with the importance of the governmental aim, but their autonomy. Again, the interests of protectees are part of the constitutional picture. The basic question is this: Are the interests of addressees strong enough to justify the governmental inroad into the efficacy of private regulation? The juxtaposition of freedom and autonomy also helps to find a measuring rod for this comparison. In the domain of fundamental freedoms, the level of protection is, among others, a function of the constitutional status of the respective freedom. If government intervenes into, say, the freedom of life and limb, it comes under closer constitutional scrutiny than if it intervenes into commercial freedoms ${ }^{68}$. The general freedom of article 2, par.1, Basic Law, is the least protected ${ }^{69}$. Likewise, a private regulatory body deserves greater protection when it can rely on a specific constitutional guarantee of autonomy, like the municipalities in Article 28, par.2, or the unions in Article 9, par.3, Basic Law. Conversely, the legislator has greater freedom to intervene into private regulation if the latter's autonomy is only protected by the general clause of Article 9, par.1, Basic Law.

As developed as this solution appears, there is still dogmatic work to be done. On the basis of the distinction between freedom and autonomy, the interests of the protectees become constitutionally visible; but they are not given full justice. The missing bit is this: Thus far, 
the private regulator has been able to defend himself by his interest in good regulation. But how can he introduce a comparative argument? How can he claim that he does a better job than alternative institutional arrangements? And in particular, how can he introduce the idea that government itself could do no better? There is a more general and a more specific way to address this challenge. The more general approach starts from the observation that the efficacy and, more generally, the quality of regulation lack proper constitutional status ${ }^{70}$. The neglect becomes understandable if one looks at the type of conflicts for which fundamental freedoms have been developed. In the past, government unilaterally interfered with individual freedom. But constitutional practice came to realise that most conflicts actually do not exclusively oppose the government and its citizenry. Usually governments only interfere with the freedom of one citizen out of interest in the freedom of another. Constitutional law has already drawn the conclusion that fundamental freedoms can be turned into duties to protect ${ }^{71}$. Accordingly, introducing the idea of regulatory efficacy into the application of the principal of proportionality would only be the next logical step.

However, for our purpose it is not necessary to go that far. We can again stress the distinction between freedom and autonomy. The basic purpose of the distinction is to do justice to the interests of the protectees. But that purpose does not justify stopping half way to allow a defence which argues that alternative regulatory arrangements would be worse.

Good governance is not a value as such. To use an obvious example: The governance exercised by the Mafia seems to be conspicuously effective, but it is also obviously socially harmful. Good governance in itself is therefore not a valid defence from governmental interference into the affairs of private regulators. The principle of proportionality re-enters the scene. If he uses this defence, the private regulator must show that he is pursuing a legitimate end, that his regulatory tools are conducive to that end, that they are the least intrusive tools with that degree of effectiveness, and that they are not overly onerous for the addressees ${ }^{72}$. And the private regulator cannot be left to define legitimate ends. Even if it leaves room for some private governance, the constitution must retain the monopoly for decisions about the legitimacy of regulatory aims.

70 Wolfgang Hoffmann-Riem: Effizienz als Herausforderung an das Verwaltungsrecht - Einleitende Problemskizze, in: id./Eberhard Schmidt-Assmann (ed.): Effizienz als Herausforderung an das Verwaltungsrecht (Schriften zur Reform des Verwaltungsrechts 5) Baden-Baden 1998, 11 - 59 (31 s.) alludes to this.

$71 \quad$ More on this below $4 \mathrm{~b}$.
} 
Let us assume that the private regulator can show all this. His own regulatory activities can then be compared to hypothetical alternative activities by the government or by third private regulators. For traditional constitutional lawyers, the first part of the comparison might appear almost blasphemous; for it openly contradicts the idea of sovereignty. It assumes that the government is no longer able to introduce whatever regulation it deems fit. Alternatively it assumes that the cost for doing so may not only be high in practice, but that such cost-benefit analysis has constitutional status. One may argue that such iconoclastic hypotheses destroy the illusions that are necessary for the proper functioning of the legal system. Were the inroads into the efficacy of governmental regulation only marginal, this would be plausible. But reality and public perception are different. Globalisation has even popularised the grossly overstated idea of the demise of the nation-state. In such a situation, it would not be wise for the law to ignore the challenges. Constitutional law should adapt to them.

Basically there are two challenges. The first is indeed globalisation, the second systems autonomy $^{73}$. In two landmark decisions, constitutional law has addressed the former challenge. The first decision concerns the treaty by which France gave the occupied land of the Saar back to Germany. In a lot of respects this treaty did not meet the standards of the Basic Law. The Constitutional Court nonetheless upheld it. The basic argument was this: had the court insisted on strict constitutional standards, the Saar would have remained under French occupation ${ }^{74}$. The second case concerns the registration of vessels. Registration is decisive for the law applicable to the vessel, and in particular for labour law. If a vessel cruises the oceans, it does not matter for its owner which country it is registered in. More and more German ship owners have realised the advantages of lower foreign standards and have registered their vessels under flags of convenience. The German legislator reacted by introducing a second German registry. Ships registered in it were free from most provisions of German labour law. Again, the Constitutional Court upheld the statute. Abiding by the full

\footnotetext{
72 For greater detail see above $b-d$.

73 Basic on the importance of the latter for the law Gunther Teubner: Recht als autopoietisches System, Frankfurt 1989; more on the importance for the principle of proportionality from Christoph Engel: The Constitutional Court - Applying the Proportionality Principle - as a Subsidiary Authority for the Assessment of Political Outcomes, in: id./Adrienne Héritier (eds.): Common Goods: Reinventing European and International Governance, Boulder (forthcoming).

$74 \quad$ BVerfGE 4, 157, 169; for a summary of the literary discussion on the decision see Christoph Engel: Völkerrecht als Tatbestandsmerkmal deutscher Normen (Tübinger Schriften zum internationalen und europäischen Recht 19) Berlin 1989, 166-175.
} 
constitutional standards would have been little more than a front. Safeguarding some constitutional influence by deliberately lowering the standards seemed the better alternative ${ }^{75}$.

The idea can be transposed to situations inside the territorial state. For the regulatory power of government is not only limited by the option to exit from the nation-state and the ensuing regulatory competition between nations ${ }^{76}$. Systems theory convincingly shows that societal sub-systems do need autonomy ${ }^{77}$. But like any pertinent observation, the claim of systems theory can be overstated. It should not be misread as saying that any governmental attempt to govern other sub-systems is futile $\mathrm{e}^{78}$, but as saying that systems autonomy has an impact on the comparison between public and private regulation. The greater the autonomy of a sub-system, the more difficult and costly public intervention will normally be.

The comparison between regulatory activities by one private body and the actual or potential regulation by other private bodies is not plagued by a similar constitutional hesitation. The comparison is therefore a fortiori relevant for the intervention into private regulations in accord with the proportionality principle. It does not help the constitutional claimant, but the government. The interference is easier to justify if the government can show that other private bodies do, or could do a better regulatory job.

Like any dogmatic tool, the forgoing framework for the constitutional analysis of interference into private governance has to be handled with prudence. If pushed to the extreme, it would enable the Constitutional Court to enact an independent constitutional policy. The organisation and procedure of the Constitutional Court is not prepared for that. Nor does the court dispose of the democratic legitimacy that would enable it to defend its decisions from public attacks ${ }^{79}$; but this is not a specific problem for the constitutional

BVerfGE 92, 26.

From the large literature on regulatory competition see only the following three titles: Lüder Gerken (ed.): Competition Among Institutions, Houndmills 1995; Markus Müller: Systemwettbewerb, Harmonisierung und Wettbewerbsverzerrung. Europa zwischen einem Wettbewerb der Gesetzgeber und vollständiger Harmonisierung (Wirtschaftsrecht und Wirtschaftspolitik 163) Baden-Baden 2000; Henri I.T. Tjiong: Breaking the Spell of Regulatory Competition. Reframing the Problem of Regulatory Exit (Preprints aus der Max-Planck-Projektgruppe Recht der Gemeinschaftsgüter Bonn 2000/13).

For a succinct introduction into systems theory see Niklas Luhmann: Ökologische Kommunikation. Kann die moderne Gesellschaft sich auf ökologische Gefährdungen einstellen? Opladen ${ }^{3}$ 1990; another conceptual possibility for making the same point is offered by Gerhard Wegner: Wirtschaftspolitik zwischen Selbst- und Fremdsteuerung. Ein neuer Ansatz (Contributiones Jenenses 3) Baden-Baden 1996, Wegner stresses the possibility that addressees react creatively to governance impulses.

Convincing Teubner (note 73) 81-122.

More on this by Christoph Engel: Delineating the Proper Scope of Government - a Proper Task for a Constitutional Court? (Preprints aus der Max-Planck-Projektgruppe Recht der Gemeinschaftsgüter Bonn 2000/9). 
protection of regulatory autonomy. Again, the dogmatic distinction between the protection of freedom and of autonomy is helpful. In dealing with complaints based on fundamental freedoms, the Constitutional Court has developed a whole array of techniques for avoiding overly stringent decisions: it deliberately lowers the density of its control ${ }^{80}$; it acknowledges the prerogative of the legislator in assessing the facts and the need for intervention; and it grants the legislature leeway for prognostic judgement ${ }^{81}$.

\section{f) Solutions}

The application of the dogmatic framework thus developed will often lead to a clear answer: for example, that the government has been justified in interfering with private regulation, or that it has clearly overstepped the limitations provided by the constitutional protection of autonomy. But in other cases the result will not be that obvious. In these cases it will be necessary to consider intermediate solutions. The following section sketches out what such intermediate solutions might look like.

A first line of compromise draws on a seemingly far-fetched parallel: namely, with arbitration, which poses similar problems. Arbitration is an inroad into the state monopoly of adjudication. The legal order gives private litigants liberty to compose their own court. But the legal order retains the monopoly of power for enforcing arbitral awards. And it gives the parties an exceptional injunction. The state courts are only allowed to step in if the outcome of arbitration grossly violates a standard of state law. Public scrutiny of arbitration, organisation and procedure is much stricter, however ${ }^{82}$. This is also a useful blueprint for the treatment of private regulation, if and when the legal order does not combat it in principle. In those cases it ought to be reluctant to intervene in regulatory substance. But it ought to oversee the organisation of the regulatory body, and its procedure.

From the literature see only Werner Heun: Funktionell-rechtliche Schranken der Verfassungsgerichtsbarkeit. Reichweite und Grenzen einer dogmatischen Argumentationsfigur (Studien und Materialien zur Verfassungsgerichtsbarkeit 50) Baden-Baden 1992.

BVerfGE 50, 290, 332 s.; more from Indra Spiecker gen. Döhmann: Staatliche Entscheidungen unter Unsicherheit. Juristische und ökonomische Vorgaben (Preprints aus der Max-Planck-Projektgruppe Recht der Gemeinschaftsgüter Bonn 2000/10).

82 For the details see $\S \S 1025-1065$, and $\S 1059$ Zivilprozeßordnung in particular; for a political scientists perspective on arbitration see Dirk Lehmkuhl: Commercial Arbitration. A Case of Private Transnational Self-Governance? (Preprints aus der Max-Planck-Projektgruppe Recht der Gemeinschaftsgüter Bonn 2000/1). 
One pervasive concern of the public is that private regulators choose to solve true regulatory problems in ways that asymmetrically serve those regulators' personal interests ${ }^{83}$. Artificially introducing or fostering competition among several private regulatory bodies is a useful way of addressing the concern ${ }^{84}$. The approach includes incentives for the addressees of private regulation to organise themselves. They can limit their co-operation to their common pursuit to acquire bargaining power. But they can also directly offer the protectees protection $^{85}$.

More intrusive intervention is precisely what triggered this article. What we are looking for are solutions that preserve the advantages of private regulation for efficacy, but introduce checks and balances for the protection of addressees' interests or other public interests. Adding some public elements to private regulation is often meant to do this ${ }^{86}$. One might call this the hybridisation of private regulation.

\section{Other disputes between private regulators and government}

The hypothetical dispute between a private regulator and the government over interference, aimed at protecting the addressees, has served to introduce the basic dogmatic tools. We can now apply them to other disputes that might originate from private regulation. A first set still opposes private regulators and government, but in regard to different conflicts: the first addresses a conflict in a private regulatory body (a); the second is triggered by a conflict between competing private regulators (b); the third by competition between private and public regulation (c).

\section{a) Conflicts in private regulatory bodies}

When analysing the conflict between a private regulatory body and its addressees, we already had a look inside the regulatory body. But at that point we were exclusively concerned with the regulatory effect ${ }^{87}$. We deliberately left aside the principle-agent problem between the

\footnotetext{
83 See above b.

84 On other instances of deliberate competitive pressure on regulation see Christoph Engel: Legal Experiences of Competition Among Institutions, in: Gerken (note 76) 89-118 (108-115).

85 Cf. Kenneth W. Dam: Self-Help in the Digital Jungle (Chicago John M. Olin Law and Economics Working Paper No. 59) Chicago 1998, 10 s. and passim.

86 For some details see below IV.

87 See above 2 a.
} 
management of the body and its members. It is now time to take it up. Parallel to our first case, we assume that government wants to step in. It legislates on behalf of the members. Visually, that scenario looks as follows:

\begin{tabular}{|l|c|c|c|c|c|}
\hline & protectee & addressee & $\begin{array}{c}\text { private } \\
\text { regulator } \\
\text { members }\end{array}$ & $\begin{array}{c}\text { private } \\
\text { regulator } \\
\text { management }\end{array}$ & government \\
\hline dispute & \multicolumn{3}{|}{$\longrightarrow$} \\
\cline { 1 - 2 } conflict & & & \\
\hline
\end{tabular}

We already know the two ideal types for managing control mechanisms: voice and exit ${ }^{88}$. If the government makes it easier for the members of a regulatory association to leave it, it can rely on established jurisprudence. We already know that government has a legitimate aim if it protects the holder of one fundamental freedom from another ${ }^{89}$. The Constitutional Court derives what it calls a negative freedom from Article 9, par.1, Basic Law. The constitution not only guarantees the right to become a member of an association, it equally guarantees the right to remain outside of one ${ }^{90}$. This includes the right to leave the association. Likewise, article 9, par.1, Basic Law, enables the legislator to introduce additional voice mechanisms ${ }^{91}$.

\section{b) Conflicts between competing private regulators}

The second scenario is characterised by a dispute between a private regulator and government over a conflict between competing private regulators. In our already familiar drawing, this scenario looks as follows:

See again Hirschman (note 60).

See above 2 b.

BVerfGE 10, 89, 102.

BVerfGE 50, 290, 354 s. - Mitbestimmung. The court does not use the dogmatic tools thus developed. Instead it relies on an extra limitation to fundamental freedoms for the development of abstract legal regimes. Basic on this Gerd Morgenthaler: Freiheit durch Gesetz. Der parlamentarische Gesetzgeber als der Erstadressat von Grundrechten (Jus Publicum 40) Tübingen 1999; Martin Gellermann: Grundrechte in einfachgesetzlichem Gewande. Untersuchung zur normativen Ausgestaltung der Freiheitsrechte (Jus 


\begin{tabular}{|c|c|c|c|c|c|}
\hline & protectee & addressee & $\begin{array}{c}\text { private } \\
\text { regulator } \\
1\end{array}$ & $\begin{array}{c}\text { private } \\
\text { regulator } \\
2\end{array}$ & government \\
\hline dispute & & & & & $\rightarrow$ \\
\hline conflict & & & 4 & $\longrightarrow$ & \\
\hline
\end{tabular}

Private regulation is not a new phenomenon ${ }^{92}$, but public interest in it is. This explains why there is no coherent legal framework for private regulation yet, no general part so to speak. Establishing a field with such a set of rules would make at least as much sense as the wellestablished fields of corporation and antitrust law. Such rules would give the founders of new regulatory bodies some guidance, and they would see to the interests of the public, outsiders and internal minorities. One basic normative task neglected by the legislator thus far is the development of a set of ground rules for regulatory competition. Admittedly, chances are that antitrust law would be applied to competition among private regulators ${ }^{93}$. But these rules are not well-prepared for the task. The reasons are basically the same as those that justify the distinction between freedom and autonomy in constitutional law ${ }^{94}$. Antitrust law is blind to the interests of protectees. It is geared to the interests both of competitors and of the other market side. In the ordo-liberal tradition, German antitrust law also pays some attention to the interests of the public. But not even this subsidiary perspective of the field is appropriate for addressing regulatory competition. It is exclusively interested in protecting the public from political power that results from economic power ${ }^{95}$. If, however, the legislator edicts rules on regulatory competition, they have to be tested for their compatibility with the constitutionally protected autonomy of regulators. Consequently, the legitimate aim is not to protect the freedom of the involved competitors, but to protect their autonomy. For the application of the principle of proportionality, not only do the interests of the competing regulators count, so do the interests of protectees ${ }^{96}$.

Publicum 61) Tübingen 2000; critical Christoph Engel: Rundfunk in Freiheit, in: Archiv für Presserecht 1994, 185-191.

Stimulating Milos Vec: Aushöhlung des Staates? Selbst-Normierung im Staat der Industriegesellschaft als historisches Problem, in: Rechtshistorisches Journal 19 (2000) 517-532.

The decisive question is whether the courts would treat private regulation as an entrepreneurial activity.

See above 2 a.

See only Ernst-Joachim Mestmäcker: Wirtschaftsordung und Staatsverfassung, in: id.: Recht und ökonomisches Gesetz. Über die Grenzen von Staat, Gesellschaft und Privatautonomie (Wirtschaftsrecht und Wirtschaftspolitik 50) Baden Baden ${ }^{2}$ 1984, 33-68.

Cf. above 2 e. 
From the viewpoint of constitutional law, the third scenario looks most familiar, as our drawing demonstrates:

\begin{tabular}{|c|c|c|c|c|}
\hline & protectee & addressee & private regulator & Government \\
\hline dispute & & & & $\rightarrow$ \\
\hline conflict & & & & \\
\hline
\end{tabular}

From an outside perspective, competition between private and public regulation is not fundamentally different from competition among several private regulators. But the constitution is itself part of the legal order. It might therefore be biased in favour of public regulation. If this turns out to be true, governmental interference into private regulation might be easier to justify, so long as it protects public regulation. The bias can come in two dogmatic forms: the first is in the definition of legitimate aims, the second in the standard of control under the principle of proportionality.

The bias would be strongest if government could justify intervention into private regulation by simply pointing to the constitutional rules on jurisdiction to prescribe. Since the constitution starts from the concept of sovereignty, this jurisdiction is in principle unlimited. The constitution is only interested in distributing jurisdiction between the federation and the Länder. But this approach would basically allow any act of interference into private regulation. It would be inconsistent with the fact that the constitution does indeed protect autonomy, not only freedom. If the government overrules private regulatory activities, in principle it must therefore also show why public regulation is preferable to private regulation in the case at hand. But it will not be difficult for government to find such reasons. For only public regulation is embedded in dense safeguards for democracy and the rule of law. But in this context, the interest of the protectees is not to be overlooked either. When that protection is itself constitutionally legitimate, private regulators must therefore be allowed to show that they give protectees much better protection. The constitutional bias in favour of public regulation is therefore, at most, limited. If it becomes hard to say whether private regulation is indeed preferable, public intervention may prevail. 
Since the constitution protects autonomy, a second line of justification is insufficient. It would rely on the fact that widespread and efficacious private regulation might delegitimise public regulation in the long run. This fear would only make for a legitimate aim if there were a realistic chance that government at some point might not be able to reach legitimate regulatory aims. Protecting its own turf in regulatory competition is not itself constitutionally legitimate. This is a further reason for the constitutional protection of autonomy. Fundamental freedoms are a reaction to the temptation of those in government to further their individual interest in power by disregarding liberty. Likewise, the constitutional protection of autonomy is the reaction to the temptation of those in government to disregard the valuable private generation of order in the interest of maintaining or increasing political power.

\section{Disputes between addressees and government}

We started our analysis by looking at disputes between private regulators and government. A second series of constitutional cases opposes the addressees of private regulation and government. Addressees can pursue two fundamentally opposed interests: they can ally with private regulators in their defence against public intervention (a); on the contrary, they can call for such intervention (b).

\section{a) Protection from public intervention into private regulation}

Again, it may be helpful to start by placing the dispute into the framework of our drawing:

\begin{tabular}{|l|c|c|c|c|}
\hline & protectee & addressee & private regulator & government \\
\hline dispute & \multicolumn{3}{|}{$\longrightarrow$} \\
\hline conflict & & & \\
\end{tabular}

The addressees of private regulation can have both a direct and an indirect interest in maintaining that regulation. Private regulation benefits them directly if it gives them an advantage in relation to the protectees. In one typical situation the addressees of private regulation are producers, the protectees their customers. Producers can have an interest in 
pointing to private regulation if it addresses some concern of customers. Such is the case in the example used repeatedly: The standards of good medical practice enforced by the association make is possible for doctors to sell their services to patients, despite their character as credence goods. Producers are particularly affected by the governmental intervention if substitute public regulation is less efficacious. They can then rely on their constitutionally protected commercial freedoms, in particular Article 12, par.1, Basic Law.

The addresses' indirect interest originates from a comparison between private regulation and a public substitute. The substitute can be more onerous. In practice, this is a frequent concern of addressees; for most private regulation is not imposed on addressees, but negotiated with them.

In the first situation, the addressees simply ally with the private regulators in their defence against governmental intervention. The second case can be procedurally more demanding. If intervening into private regulation and replacing it with public regulation occur in one and the same act, the addressees have no immediate right to sue. They have to wait until the public substitute comes into force ${ }^{97}$.

\section{b) Call for protection against private regulation}

The alternate scenario graphically looks as follows:

\begin{tabular}{|c|c|c|c|c|}
\hline & protectee & Addressee & private regulator & government \\
\hline dispute & & & & $\rightarrow$ \\
\hline conflicts & & & - & \\
\hline
\end{tabular}

This scenario is dogmatically much more challenging than the previous. The addressees of private regulation call for governmental protection. Why is this the government's business? There are two options: attribution, and a constitutional obligation to intervene on behalf of the addressees. In the first perspective, what looks like private activity of non-governmental 
regulators is interpreted as governmental action. In the second perspective, the constitutional issue is not action, but omission. It presupposes a government's constitutional obligation to intervene. The first option is hard to defend; for private regulators do not exercise delegated governmental powers. The addressees might at best claim that government has left them at the mercy of private regulation. But even if government has done so deliberately, it does not take on any responsibility for the regulatory action. Allowing private regulation to occur is not the same as delegating public regulatory power. The only appropriate dogmatic figure is therefore an obligation to intervene ${ }^{98}$.

But is there actually such a constitutional obligation for government to intervene on behalf of the addressees of private regulation? There are again two dogmatic options. According to the first, fundamental freedoms directly oblige private regulators. If that were true, the government might be obliged to intervene as the executive arm of the constitution. According to the second, it is not the private regulators who are obliged by the constitution, but only the government. But if one private actor intrudes into the constitutionally protected sphere of another, government will be obligated to protect the latter. Private regulation is different from mere private power. This is why we earlier distinguished autonomy from freedom ${ }^{99}$. Along the same lines, one might regard private regulators as directly obliged by fundamental freedoms. For a long time this has indeed been the jurisprudence of the Federal Court of Labour Law with regard to the collective agreements between unions and employers' associations ${ }^{100}$. And it has never been doubted that the municipalities are bound by the fundamental freedoms when they exercise their regulatory autonomy. But the large majority of constitutional lawyers opt for the second solution, the mere duty to protect ${ }^{101}$. Meanwhile even the Federal Court for Labour Law has given in ${ }^{102}$.

This is not the right place for engaging in this doctrinal battle. If one follows the majority, however, the distinction between private freedom and private autonomy inevitably affects the interpretation of the duty to protect. If two fundamental freedoms clash, the government's

BVerfGE 1, 97, $101 \mathrm{~s}$. This procedural situation is somewhat unsatisfactory, if the private regulatory body is already dismantled when the Constitutional Court finally decides upon the constitutional complaint of the addressees.

Out of the rich literature see only Matthias Schmidt-Preuss: Verwaltung und Verwaltungsrecht zwischen gesellschaftlicher Selbstregulierung und staatlicher Steuerung, in: Veröffentlichungen der Vereinigung der deutschen Staatsrechtslehrer 56 (1997) 160-234 (172); Di Fabio (note 62) 254.

See above 2 a.

See BAGE 1, 185, 193.

Comprehensive Stern (note 58) 76.

BAGE 52, 88, $97 \mathrm{~s}$. 
position resembles that of a neutral arbitrator. Conflicts between freedoms and autonomy, however, are asymmetrical from the outset. The addressees of private regulation do not ask for constitutional protection from private power, but for protection from a normativity that is not controlled by the constitutional safeguards of democracy and the rule of law. Constitutional law is rightly reluctant to find for a violation of duties to protect if two freedoms clash ${ }^{103}$. Similar reluctance is not be justified if freedom and autonomy are in conflict.

From the forgoing, a second peculiarity can be derived. If freedom clashes with freedom, the government's constitutional duty can only consist of offering substantial protection. Government must hinder one private actor from intruding too deeply into the constitutionally protected freedom of another. This may also be necessary if freedom clashes with autonomy. But the constitutional concern with autonomy does not end there. In principle, the constitution prefers regulation that is controlled by democratic institutions and by the rule of law. As we have seen, this constitutional value judgement is not absolute. That would be tantamount to a constitutional interdiction of private regulation ${ }^{104}$. But the constitutional value judgement is translated into a duty to protect individuals from forms of governance that fall far behind the constitutional standards of democracy and the rule of law. In other words, the duty to protect someone from autonomy can also have an effect on procedure. Vice versa, as long as private regulation ensures acceptable procedural standards, the government might not constitutionally be obliged to control the substance of private regulation.

The dogmatics of constitutional duties to protect are not fully settled yet ${ }^{105}$. Again, this is not the right place to offer a personally favoured solution. The following thus merely lists counter-arguments a government could offer if it did not want to intervene. The first defence is straightforward, but of considerable practical importance. Government intervention makes no sense where the government lacks power to oblige the private regulator. We have already considered the two main reasons. The private regulator might be beyond German sovereign control. Or it might be impossible to overstep systems autonomy ${ }^{106}$. However, for the most part these obstacles are still surmountable. If the private regulator acts from a foreign territory, it might still be possible for the German government to undertake diplomatic action,

\footnotetext{
103 Characteristic BVerfGE 88, 203.

104 See above 2 a.

105 For an overview see again Dietlein (note 13).

106 See above 2 e.
} 
or it might hold the property of the regulator as ransom ${ }^{107}$. And government can disregard systems autonomy by artificially increasing the resonance of the sub-system or even crudely destroying its self-referentiality ${ }^{108}$. But both come at a high price; and they can prevent the government from being fully effective. The defence therefore leads to a balancing act.

A second defence can also be derived from earlier observations. We have shown that private regulation may not analytically be reduced to an isolated conflict between the regulator and his addressees ${ }^{109}$. Government must therefore be able to forgo intervention if private regulation turns out to offer protectees both legitimate and proportionate protection.

\section{Disputes between protectees and government}

We still have a last set of hypothetical disputes to consider, the ones opposing protectees of private regulation and government. Again, such disputes can serve two opposite ends: in a first situation, a protectee can ally with the private regulator in opposing governmental interference (a); in the opposite situation, a protectee will want to oblige the government to intervene in private regulation (b). Since this group is already protected by the private rules, the substantive aim of such a dispute must be better private protection.

\section{a) Protection from public intervention into private regulation}

The first type of dispute is straightforward. This is demonstrated by our standard drawing:

\begin{tabular}{|l|c|l|l|l|}
\hline & protectee & addressee & private regulator & government \\
\hline dispute & \multicolumn{2}{|}{$\longrightarrow$} \\
\hline
\end{tabular}

107 For greater detail regarding Internet contents regulation see Christoph Engel: The Internet and the Nation State, in: id./Kenneth H. Keller (eds.): Understanding the Impact of Global Networks on Local Social, Political and Cultural Values (Law and Economics of International Telecommunications 42) BadenBaden 2000, 201-260 (245-258).

108 For greater detail see Teubner (note 73) 102-111.

109 See above 2 b. 
Private regulation is distinct from outright private power precisely because the private regulator does not, or at least not primarily, serve his personal interest. If he opposes governmental intervention in his activities, he primarily serves the interests of his protectees. We have seen that the constitution, by protecting autonomy, gives the private regulator himself standing to sue government. But this does not mean that the protectees are constitutionally prevented from protecting themselves. If governmental intervention thus results in less efficacious protection, the protectees can sue the government as well.

\section{b) Call for effective private regulation}

The second type of dispute is dogmatically much more demanding, as demonstrated by the drawing:

\begin{tabular}{|c|c|c|c|c|}
\hline & protectee & addressee & private regulator & government \\
\hline dispute & & & & $\rightarrow$ \\
\hline conflicts & & - & $\rightarrow$ & \\
\hline
\end{tabular}

We have seen that duties to protect can be derived from fundamental freedoms. But this dogmatic figure has been invented for the traditional triangle: One individual intrudes on the freedom of another. Government steps in to protect the victim. Can the same dogmatic figure be extended to our quadrangle? Technically, this is not difficult. Government would oblige private regulators to grant their protectees even better protection. But is government constitutionally entitled to do so? If the addressees of the hypothetical governmental intervention were protected by fundamental freedoms, the answer would surely be no. There is no constitutional obligation for one individual to further the interests of other individuals. Is the constitutional situation different if the addressee of a governmental intervention cannot rely on freedom, but only on autonomy? Such a claim is at least not implausible. The 
constitutional protection of autonomy means that government is, at most, conditionally entitled to legislate on behalf of the protectees. A correspondent constitutional obligation to grant appropriate protection fits into that picture. Or to put it differently: A constitutional obligation for private regulators to grant appropriate protection would make it more difficult for government to justify substituting public regulation for unsatisfactory private regulation.

\section{Private governance without law}

Thus far, all our hypothetical cases have assumed private governance by law. We knew that this was a rare event, but we wanted to focus the analysis on the distinction between private and public regulation. This section drops the assumption and addresses private governance without law: it shows the normative advantages of governance by law (1), and it explores dogmatic paths for bringing these advantages to bear (2).

\section{Normative advantages of governance by law}

Governance by law is not fashionable. Modernists pejoratively call it command-and-control regulation. The cruder the rationalist model, the easier it is to demonstrate the comparative advantage of fancier regulatory tools: for governance by law is not very efficacious, and the regulatory cost is rather high. But the world out there is neither rational nor simple. Unlike any other governance tool, governance by law has stood the test of time.

But the analysis need not stop there. It would certainly be preposterous to claim that our time has already uncovered all the secrets of this governance tool. But for quite a number of them, we do possess a conceptual language. This is not the occasion to elaborate on these issues in extenso ${ }^{110}$. Sketchy remarks must suffice. Governance by law is fuzzy on purpose. This property enables it to handle fundamental relativism, or incompatible normative currencies $^{111}$. If the political process ends up in partial dissent, the authorities entrusted with

\footnotetext{
110 For greater detail see Christoph Engel: Die Grammatik des Rechts (Preprints aus der Max-PlanckProjektgruppe Recht der Gemeinschaftsgüter Bonn 2000/3) 9-29.

111 For greater detail see Christoph Engel: Offene Gemeinwohldefinitionen (Preprints aus der Max-PlanckProjektgruppe Recht der Gemeinschaftsgüter Bonn 2000/16).
} 
rule application are able to finish the regulatory work $^{112}$. Its fuzziness makes governance by law disturbance-proof. It can be readjusted to external shocks, to boundedly rational $\operatorname{administrators}^{113}$, and to unexpected creative reactions from the addressees ${ }^{114}$.

Law is more than a governance impulse. Legal governance is text-bound. The authorities entrusted with rule application listen to the addressees and explain themselves. The addressees therefore know what the law is heading towards ${ }^{115}$. The discourse reminds the addressees of normative expectations ${ }^{116}$. It also provides the addressees with an opportunity to raise concern about the adequacy of the rules. In the terminology from Albert O. Hirschman, it thus serves as a voice mechanism ${ }^{117}$. By its discursive character, the law has access to the cognitive models on which the addressees base their view of the world. This feature makes it less likely that the addressees misunderstand the law's intention. Not so rarely, the law even has a chance to reshape the addressees' preferences. Governance by law is context-sensitive. It is essentially a mechanism for piecemeal engineering. It can attain path dependency ${ }^{118}$ and local resistance. Finally, the law is also inherently evolutionary ${ }^{119}$. It collects and even generates experiences and uses them to permanently reprocess governance.

A further advantage of governance by law becomes prominent when it is compared to extra-legal governance by private actors. Such governance tends to be excessively efficacious. A good example is governance by technical code. If the solution to the regulatory problem is hard-wired, it is enforced in each and every case without any further effort ${ }^{120}$. Such governance may not only be overly severe towards its addressees. It also foregoes the beneficial evolutionary effects of frictions ${ }^{121}$. Precisely because the solution was so powerful

For greater detail see Adrienne Windhoff-Héritier: Politikimplementation. Ziel und Wirklichkeit politischer Entscheidungen, Königstein 1980, 29-31.

113 For greater detail see Christoph Engel: Legal Responses to Bounded Rationality in German Administration, in: Journal of Institutional and Theoretical Economics 1994, 145-162.

114 Insight of Wegner (note 77). Cf. Renate Mayntz: Implementation von regulativer Politik, in: id. (ed.): Implementation politischer Programme II, Opladen 1983, 50-74 (65-69).

More on this by Iris Bohnet: Kooperation und Kommunikation. Eine ökonomische Analyse individueller Entscheidungen (Die Einheit der Gesellschaftswissenschaften 98) Tübingen 1997. See again Hirschman (note 60). See only the leading article by $W$. Brian Arthur: Competing Technologies, Increasing Returns and Lockin by Historical Events, in: Economic Journal 99 (1989) 116-131.

Extensively Stefan Okruch: Innovation und Diffusion von Normen. Grundlagen und Elemente einer evolutorischen Theorie des Institutionenwandels, Berlin 1999.

120 Boyle University of Cincinnati Law Review 1997 (note 50) 177; Lessig (note 50$) 136$ and passim.

121 The intuition is old, see already Joseph A. Schumpeter: Konjunkturzyklen, Göttingen 1961 [1939] 57 s.; see further Nordel Aakerman: The Necessity of Friction, Heidelberg 1993; Gernot Grabherr: Lob der Verschwendung, Berlin 1994; Stefan Okruch: Evolutorische Wirtschaftspolitik. Von der positiven zur 
in the past, it is bound to fail if the regulatory task changes. Psychologists call this phenomenon overfitting $^{122}$.

\section{Constitutional status of governance by law}

It is amazingly difficult to locate the normative advantage of governance by law in the constitution. The easiest path is an indirect one. It translates the listed advantages into legitimate aims for government intervention ${ }^{123}$. But that strategy is tantamount to giving government a constitutionally unfettered freedom to choose among governance tools. A slight limitation of this freedom might be implied by a constitutional duty to protect ${ }^{124}$. But the constitutional standards for duties to protect are not very stringent. More importantly, the focus of a constitutional duty to protect is strictly subjective. The normative advantages of governance by law would be watered down to elements of efficacious protection. One should therefore look out for supplementary elements of objective constitutional law.

So far, constitutional doctrine has shown little interest in the question. Fundamental freedoms demand that all essential governance be "prescribed by law"; so do the principles of democracy and the rule of law ${ }^{125}$. But this is normally understood as a rule for the distribution of powers between the legislator and the executive ${ }^{126}$. Only occasionally do constitutionalists ask whether the "law" also has to have a certain quality ${ }^{127}$. A second dogmatic inroad might be an element of the interpretation of fundamental freedoms. The Constitutional Court derives procedural obligations from substantive fundamental rights ${ }^{128}$. Constitutionalists occasionally ask whether this limits the freedom of government to choose a governance tool ${ }^{129}$. But that would again limit the question to its subjective dimension. A third possibility is very general.

normativen Theorie, in: Carsten Herrmann-Pillath / Markus Lehmann-Waffenschmidt (eds.): Handbuch zur evolutorischen Ökonomik, Heidelberg (forthcoming).

See e.g. Laura Martignon / Ulrich Hoffrage: Why Does One-reason Decision Making Work, A Case Study in Ecological Rationality, in: Gerd Gigerenzer / Peter M. Todd (eds.): Simple Heuristics That Make Us Smart, New York 1999, 119-140 (128 s. and passim).

Cf. above II 2 b.

See above II $4 \mathrm{~b}$.

The professional jargon calls this the "doctrine of essentiality", leading case BVerfGE 49, 89, $126 \mathrm{~s}$. Typical Hartmut Maurer: Staatsrecht, Munich 1999, § 8, R 19.

Walter Pauly: Der Regelungsvorbehalt, in: Deutsches Verwaltungsblatt 1991, 521-524 (523); cf. also Martin Schulte: Schlichtes Verwaltungshandeln. Verfassungs- und verwaltungsrechtsdogmatische Strukturüberlegungen am Beispiel des Umweltrechts (Jus Publicum 12) Tübingen 1995, 132.

German constitutionalists call this "the protection of fundamental freedoms by procedure", leading case BVerfGE 47, 46 - Sexualkunde.

Cf. Schulte (note 127) 116-123. 
It invokes the rule of law as guaranteed by article 20, par.3, Basic Law ${ }^{130}$. Those who come closest are those who ask whether the administration is legally obliged to employ a legal form whenever the issue is important enough ${ }^{131}$.

There is reason to go beyond all this. To be sure, in many situations, extra-legal governance tools are advantageous. Moreover, there is no single normative yardstick for evaluating governance tools. Or, to use a term already introduced, the comparative assessment of governance tools uses several incompatible normative currencies. This makes it paramount that the actual choice between governance tools is able to profit from direct legitimation. Accordingly, the government must have considerable leeway for the choice of governance tools. Likewise, the constitutionally protected autonomy of private regulators must in principle encompass the freedom to choose governance tools. What is missing, however, is a sort of refutable constitutional presumption for governance by law. Such a presumption would transform the long list of normative arguments for governance by law ${ }^{132}$ into a starting point for constitutional discourse with regulators. More often than not they will be able to offer acceptable reasons for the choice of other governance tools. What could be prevented, however, is the fashionable or inattentive use of extra-legal tools without proper reasons.

\section{Conclusion: From pure private to hybrid regulation}

Pure private regulation exists, but it is rare. What is becoming more and more frequent, however, are hybrid forms of governance, or mixes with public and private elements. What can we learn from the foregoing analysis that is of value for this increasingly frequent phenomenon?

The starting point remains the same. The Constitutional Court still only hears constitutional complaints that are directed against the government. Thus the material conflict must always be clothed as a dispute between a private actor and the government ${ }^{133}$. Accordingly, our analysis of pure private governance generates a set of hypotheses for the constitutional control of hybrid governance.

Cf. Pauly (note 127) Deutsches Verwaltungsblatt 1991, 521.

See in particular Pauly (note 127) Deutsches Verwaltungsblatt 1991, 521 ss.; further references by Schulte (note 127) 124; Schulte himself is opposed, id. 125-132.

See above 1.

See above II 1. 
In the first case, a private regulator sued government because it intervened into its regulatory activities on behalf of the addressees. Whether such a dispute is still admissible depends on the form of hybrid regulation. There are two obstacles: the government cannot sue itself; and hybridisation can provide the government with ways to influence private regulators that are not open to attack in court. We can roughly distinguish three forms of hybridisation. In the first case, the private actor is so close to government that he practically becomes a part of it. In the second case, the government becomes a member of a joint public-private regulatory body. In the third case, the private regulator remains an independent private organisation. Only the regulatory activities of the private regulator are influenced by the government, e.g. by the threat of onerous, unilateral public rules.

In the first case, the private regulator disappears as an independent actor. Our quadrangle collapses into the traditional triangle, where government interferes with the freedom of one group on behalf of the freedom of another group. In the second case, a separate, new regulatory body exists. But government is bound by the charter of this organisation. The charter will often make it illegal for the government to use its sovereign powers to influence the management of the body. Even if this were not the case ${ }^{134}$, however, such intervention would be highly unlikely. For the government would lose its standing in the regulatory body. The latter observation normally also holds for the third case. Legally, in this third scenario the government is not prevented from using its unilateral sovereign powers. But it typically has engaged in hybrid governance precisely because it expected this to be more efficacious.

The procedural problems are compounded with problems of substantive law. In the case of pure private regulation, the regulator could rely on his constitutionally protected autonomy to defend himself against governmental intervention ${ }^{135}$. This is no longer possible if the regulatory activity is undertaken by a joint public-private body. Otherwise government would be constitutionally protected from itself. Put differently: The constitution protects autonomy, not the privileged access of a group to sovereign powers. On the contrary, such regulatory activities must themselves be bound by the fundamental freedoms of outsiders. The comparison between pure private and hybrid regulation thus also shows why hybridisation is problematic from the perspective of the rule of law. For when the private actors become part of a joint regulatory body, they lose constitutional protection. Such protection remains theoretically possible if the government uses other forms to influence private regulators. But it 
is then particularly unwise for them to use this option. If hybridisation is the price for a governmental favour, the private regulators would lose this favour once they sued government. And if the government's power to threaten is strong enough to force private regulators into hybrid regulation, it will also be strong enough to prevent these regulators from suing the government.

One might think that a second type of dispute should be more prominent in hybrid regulation; namely, that members of a regulatory body complain about government actions at the interior of this body ${ }^{136}$. This is indeed where conflicts between government and its private regulatory partners are normally located. But it is not very likely that these conflicts will be transformed into constitutional complaints. One may even ask whether the contribution of government to management decisions in joint regulatory bodies is open to attack by constitutional complaint. But even if such complaints were admissible, they are unlikely to be made. For politically, such a complaint is tantamount to declaring that the joint regulatory body should be dissolved.

A third class of disputes, however, is both likely and important. In this scenario, the underlying conflict opposes competing regulatory bodies ${ }^{137}$. An outside body claims that the hybridisation of its competitor is unfair regulatory competition. If so, the action of a joint public-private regulator is open to attack by constitutional complaint; or at least the formation of the body must be open to attack. The outside competitor can rely on his constitutionally protected regulatory autonomy. The government must show why this interference with regulatory competition is necessary to protect the interests of the addressees or protectees of regulation.

Disputes between private regulators and the government over unfair regulatory competition are equally practical ${ }^{138}$. This is only another way of formulating a classic conflict. Hybridisation is often not in the interest of the private regulating body. Government can nonetheless force a regulating body into such a scheme by a credible threat of unilateral regulation. In other words: Government can threaten the private body with potential regulatory competition.

Hybridisation changes the character of the disputes between addressees and the government. Addressees will mostly be interested in whether the hybrid element makes it

\footnotetext{
136 See above II 3 a.

137 See above II 3 b.
} 
possible to attribute the regulatory activity to the government. If so, the constitutional control of the regulation becomes much easier. The addressees can directly complain about its contents.

Regulatory activity is bound to be attributed to the government if the private partner contributes to what in essence remains public regulation. The second case is the dogmatically demanding one: the joint public-private regulatory body. Technically, the government does not delegate public regulatory power to this new body. Is it nonetheless enough that the government has direct influence on regulatory contents via its chartered rights in the body? Might the attribution of this power even be extended to the third case? Is it enough that the government has invited or forced private actors to create the body? That it has given it a monopoly? That it has forced outsiders to become members?

If one does not want to go that far, these cases must be brought under the purview of the constitutional duty to protect the addressees ${ }^{139}$. If government is willing and clever, hybridisation can help the addressees. The regulators might even rely on the government's duty to protect in order to bring hybridisation about. But this is a risky strategy. Protection can only be efficacious if the government exploits the internal logic of private regulators. A Constitutional Court can hardly do more than invite the government to put more stress on the addressees' interests.

Conversely, these observations apply to the constitutional complaints of protectees against the government as well. Hybrid regulation can be a powerful tool for the protection of their interests. If they are convinced it is, they can rely on the government's duty to protect to bring it about ${ }^{140}$.

To sum it up: Pure private governance is a phenomenon that lends itself to stringent constitutional scrutiny. Some of the insights generated by the constitutional analysis of pure private governance can be transposed to hybrid regulation. But hybrid regulation poses much stronger dogmatic and practical challenges to the constitution. 